\title{
Valorization of Wastes From Agrofood and Pulp and Paper Industries Within the Biorefinery Concept: Southwestern Europe Scenario
}

\author{
Aloia Romaní, Michele Michelin, Lucília Domingues, José A. Teixeira \\ University of Minho, Braga, Portugal
}

\section{Contents}

$\begin{array}{ll}\text { 1. Introduction } & 487\end{array}$

1.1 Residue Valorization Within a Biorefinery: Current Scenario in Europe 487

1.2 Residue Fractionation: First Step in a Biorefinery 488

2. Main Industrial Processes and Wastes in Southwestern Europe 491

2.1 Residues From Pulp and Paper Mills 491

2.2 Wastes From Wine-Making 493

2.3 Brewery Wastes $\quad 495$

2.4 Residues From the Dairy Industry 498

3. Conclusions and Perspectives $\quad 500$

$\begin{array}{ll}\text { Acknowledgments } & 501\end{array}$

$\begin{array}{lr}\text { References } & 501\end{array}$

\section{INTRODUCTION}

\subsection{Residue Valorization Within a Biorefinery: Current Scenario in Europe}

The European Union (EU) is encouraging the promotion of energy from renewable sources by application of its legislation to attain a sustainable growth based on bioeconomy. Renewable Energy Directive (2009/28/EC) has targeted for the EU to have 20\% of its final energy consumption provided by renewable sources by 2020. It also includes a substitution of a minimum of $10 \%$ transport fuel by biofuels from renewable sources, aiming to meet a set of mandatory sustainability regulatory rules to achieve greenhouse gas reductions and to mitigate risks related to areas of high biodiversity value and areas of high carbon stock. Moreover, legislation establishes that biofuels must be produced by environmentally friendly processes. In this context, biorefinery development is considered an appropriated strategy for the suitable use of renewable sources. The biorefinery is based on the raw materials processing for bio-based products, chemicals, and fuels manufacturing as an alternative to the petroleum refinery $[1,2]$. 
Residues and wastes generated from industrial and agrofood processes are considered renewable feedstock enriched by bio-based compounds $[3,4]$ that can be reused and recycled to produce energy and other value-added products satisfying environmental EU policy at laying the foundations for the circular economy [5].

Identification and quantification of suitable residues to be used in a biorefinery scheme are essential to attain a feasibility of Europe's transition toward productive growth based on a sustainable use of resources. Many of the residues generated in Europe have got an existing use, for example, sawdust, a "waste product" of wood production, which is used to make products such as fiberboard, and some crop residues as animal feed or agricultural activities. Therefore, only one fraction of these wastes (225 million tons per year) could be considered to feed a biorefinery. Among these wastes, the following are included: crops residues, 122 million tons/year; municipal waste (paper, wood, food, and gardens), 63 million tons per year; and forestry residues, 40 million tons per year [6].

Most of the studies and reports about the availability of lignocellulosic residues in Europe collect data considering energetic purposes (mainly biofuels from the cellulosic fraction or for thermal energy). However, literature has not addressed other potential uses and/or mapping of resources availability from a biorefinery perspective [7].

In Europe, 30\% of the residues are constituted mainly by agricultural and forestry wastes. Residues derived from crops (as wheat, rye, barley, oats, maize, rice, rapeseed, and sunflower) could help to satisfy $1530 \mathrm{PJ} /$ year of energy needs [8]. Nevertheless, the main inconvenience of agricultural residue use is related to temporal variations. Therefore, it is pertinent to consider residues from other sources. Forestry biomass is the most important renewable resource of energy in Europe. Forest resources have an estimated bioenergy potential of 1400-5400 PJ/year [9]. On the other hand, residues from food supply chain may also constitute an important source for bio-based processes development [4].

Therefore, the residues generated in industrial processes represent an alternative renewable source being an opportunity for employing creation, reuse, and recycling of wastes, improving the economy of industrial processes and generation of new market opportunities. Nevertheless, a suitable waste processing to obtain value-added compounds needs a profound knowledge of its chemical composition and structural disposal for a successful fractionation.

\subsection{Residue Fractionation: First Step in a Biorefinery}

The bioconversion or valorization of lignocellulosic residues and industrial wastes into biofuels, biochemical, and biomaterials within a biorefinery scheme (using green technologies) seems an interesting strategy to satisfy economic and sustainable desirable goals. The valorization of residues can be carried out by two approaches: (i) the global use of the residue (as a whole without previous separation) and (ii) the use of residue fractions (with previous selective separation). The global use includes methods of combustion, 
gasification, pyrolysis, or liquefaction. On the other hand, the fractionated use of these residues is an alternative to global use by selective fractionation into their main compounds. Fig. 16.1 shows a biorefinery scheme for residue valorization into value-added compounds. The main challenge of fractionated use is separating its components without chemically degrading some of them. In this sense, the fractionation process must be carefully selected taking into account all components' recovery.

Therefore, the technology employed for fractionation is dependent on the raw material composition, crystallinity index, and physical features. Agricultural and forestry wastes are considered lignocellulosic materials mainly composed of cellulose, hemicellulose, and lignin. These fractionation processes can be classified, considering the main fraction obtained, in (i) delignification methods (solubilization of lignin by organosol and alkali pretreatments) and (ii) hydrolysis of polysaccharides (solubilization of polysaccharides by acid or enzymatic hydrolysis).

The first required step in a biorefinery consists of a process, needed to alter the recalcitrant structure of lignocellulosic biomass, commonly known as pretreatment. Some authors classify the pretreatments according to their nature in chemical, physical, physicochemical, and biological pretreatment [10]. The pretreatment aims (i) to increase surface area and porosity of the biomass, (ii) to reduce the crystallinity of cellulose, and (iii) to disrupt the heterogeneous cellulosic structure of materials [10]. The pretreatment modifies the lignocellulose biomass structure by hemicellulose solubilization or by removing the lignin. In general, all pretreatments can change the lignin structure and disrupt the crystalline configuration. The chemical composition of the resulting pretreated biomass changes according to the chosen pretreatment, being possible to obtain streams with variable composition: (i) the spent solids with modifications in their structure (using pretreatments as ionic liquids), (ii) the spent solids (composed of cellulose and lignin) and a liquid phase composed of hemicellulose-derived compounds (using pretreatments such as autohydrolysis, steam explosion, or diluted acid), and (iii) the spent solid composed of cellulose and hemicellulose and a liquid phase or "black liquor" containing solubilized lignin (using pretreatments such as organosol or alkaline).

Besides, the "ideal" pretreatment must satisfy some of these following requirements: (i) to have a simple and economical operation; (ii) to need limited requirements of energy, water, and chemicals; (iii) to avoid equipment corrosion; (iv) to have the ability to alter the structure of lignocellulosic biomass; (v) to be selective toward polysaccharide losses; (vi) to recover high valuable products as hemicellulose-derived compounds; (vii) to produce a limited amount of undesired degradation products; (viii) to produce substrates with high cellulose content, susceptible toward enzymatic hydrolysis; (ix) to generate high-quality lignin and/or lignin-derived products; and (x) to generate a limited number of wastes. So far, no single method of pretreatment was found to meet all these requirements. As an alternative, different methods can be combined for the biomass processing $[11,12]$. 


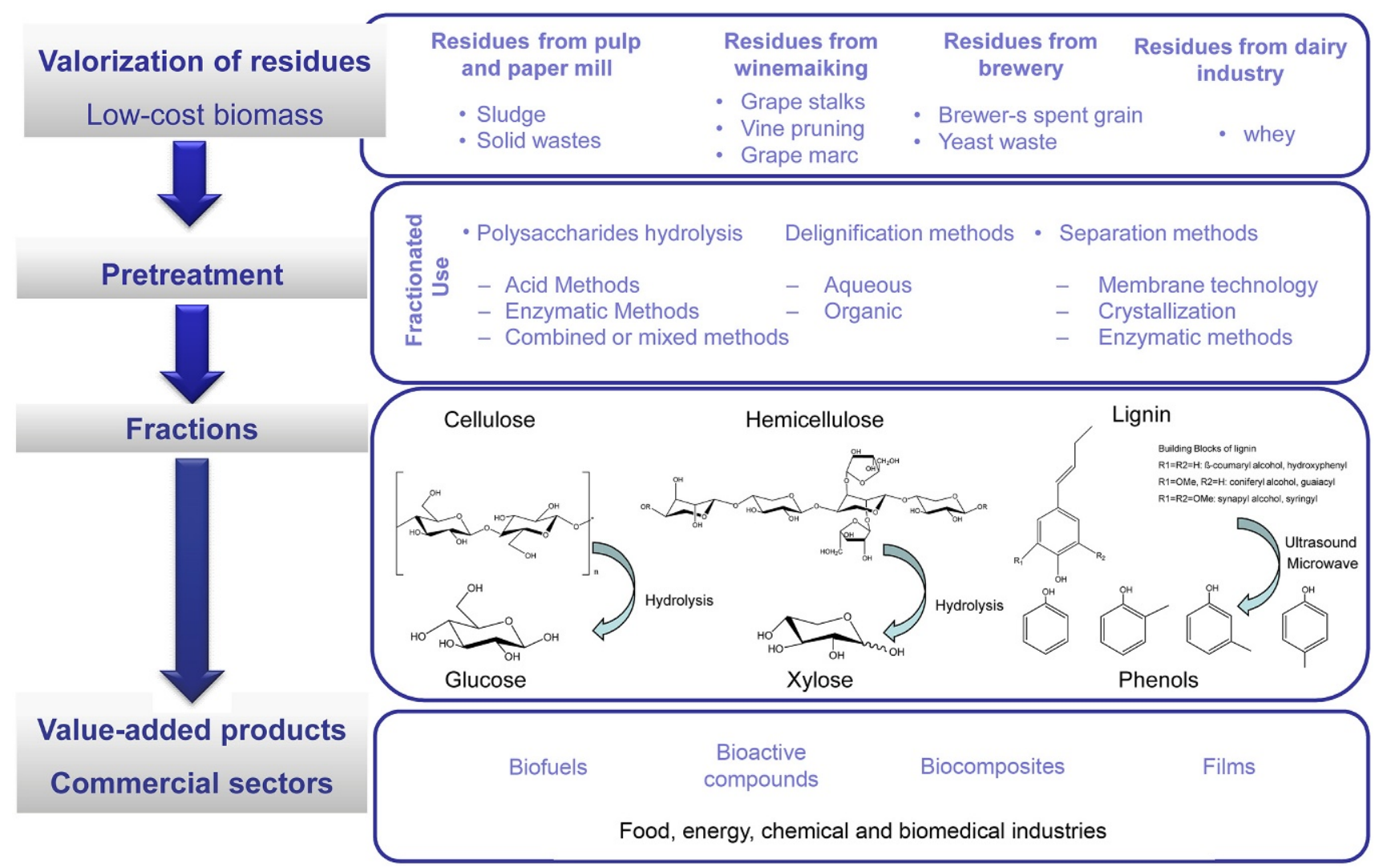

Fig. 16.1 Scheme representation of residue valorization within a biorefinery. 
Among those considered to be "green" pretreatments or technologies, hydrothermal treatments, assisted or not with microwave, combined with enzymatic hydrolysis for biological compound production have been proposed for valorization of lignocellulosic biomass in a biorefinery scheme. In these processes, aqueous suspension of residues is heated to cause hydrolytic depolymerization of hemicellulose, obtaining a liquid phase enriched in hemicellulose-derived compounds (oligosaccharides). A solid phase that is prone to cellulose conversion into glucose using hydrolytic enzymes is also obtained [11]. These processes are considered promising and sustainable pretreatment alternatives since they fulfill most of the looked-for pretreatment requirements mentioned above [13].

The same fractionation technologies can be applied for food waste processing, but one has to consider its chemical composition. Residues from food industry can be composed of complex structures such as starch, pectin, cellulose, or hemicellulose and simple molecules such as soluble sugars, proteins, and phenolic compounds. The main difference with lignocellulosic biomass is that food waste structure is not strongly linked being easier to fractionate. On the other hand, these soluble compounds that are straightforward to fractionate may degrade at high temperatures and pressures or prolonged times.

\section{MAIN INDUSTRIAL PROCESSES AND WASTES IN SOUTHWESTERN EUROPE}

Flowcharts of the industrial processes should be identified to define the use and applied technology for the valorization of the generated residues. Some examples of industrial processes in Southwestern Europe are presented below.

\subsection{Residues From Pulp and Paper Mills}

The forestry area in Southern Europe represents 31\% in France, 35\% in Portugal, and $36 \%$ in Spain with a production of 65 million $\mathrm{m}^{3}, 13$ million $\mathrm{m}^{3}$, and 16 million $\mathrm{m}^{3}$, respectively [14]. The potential sustainable biomass production from forest residues consists of various streams, such as (i) the current production of stem wood for industry; (ii) the potential stem wood harvested within the sustainable harvest limit; (iii) the primary forestry residues, for example, logging residues, early thinnings, and extracted stumps; and (iv) the secondary forestry residues, residues from the processing of wood in the industry [2]. One of the uses of forestry biomass is the papermaking. Paper production in Spain and Portugal is based mainly on eucalyptus wood.

In Europe, pulp and paper mills generate 11 million tons of waste [15]. These wastes include pulping liquors, wood wastes, sludge, and rejects. Fig. 16.2 shows the kraft process for cellulose pulp production and the residue generation. Black liquor is the most important biomass fuel in a kraft pulp mill, containing around $50 \%$ from wood substance dissolved. However, this by-product is only used to produce energy in the pulp and paper industry. Wastewater treatment produces a large amount of sludge (the production of 


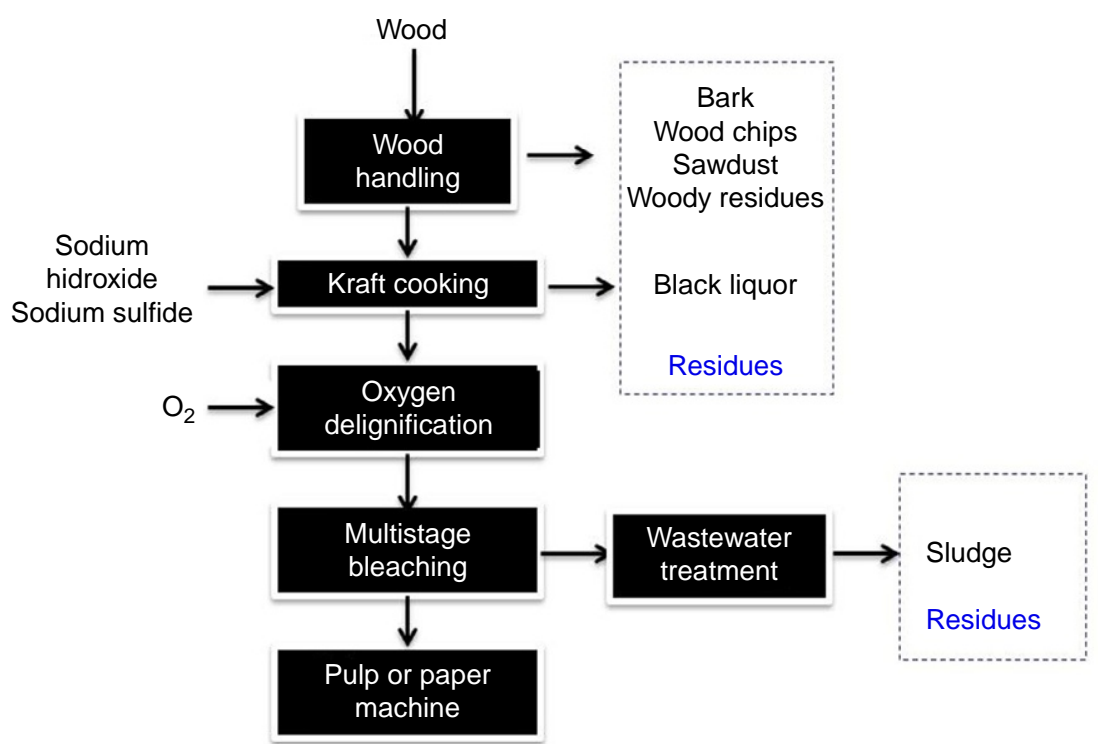

Fig. 16.2 Main stages of kraft pulp mill and residues generated.

1 ton of paper at a paper mill generates about $40-50 \mathrm{~kg}$ of dry weight sludge). In addition, several stages of processing (viz., pulping, papermaking, and deinking) generate wastewater, containing a noteworthy percentage of cellulose [16-19]. On the other hand, wood handling produces wood wastes including sawdust, bark, wood chips, and woody residues that are undesirable for papermaking due to its features. Kraft pulp mill produces approximately $160-450 \mathrm{~kg}$ of wood solid wastes per ton of oven-dry pulp [18]. The solid waste composition is known and constant being considered a lignocellulosic material. On the other hand, the composition of sludge is highly dependent on the operations performed in the paper mill.

The sludge is usually mixed with bark and burnt in a boiler to produce energy or used for landfilling. Nevertheless, these practices are associated with environmental problems. Alternatively, sludge can be used for the elaboration of ecoblocks brick made from recycled materials as activated sludge [20], for the production of activated biochar to remove organic micropollutants [21], for the biogas production [22], and for animal feed as protein supplementation source [23]. On the other hand, solid wastes contain low humidity and have a considerable heating value.

In kraft pulp mills, the last trend is the development of new pulp products to improve the efficiency of pulp and paper mills [24]. Kraft pulp mill is an excellent scenario since it provides a platform for the cellulose processing that is able to be adapted to other new products. Table 16.1 presents several value-added products obtained from a biorefinery of pulp and paper residues that include a necessary treatment for the extraction or 
Table 16.1 Valorization of residues from pulp and paper mills: pretreatment used and main product obtained

\begin{tabular}{|c|c|c|c|c|}
\hline $\begin{array}{l}\text { Raw } \\
\text { material }\end{array}$ & Pretreatment & Fraction & $\begin{array}{l}\text { Value-added } \\
\text { product }\end{array}$ & Reference \\
\hline $\begin{array}{l}\text { Eucalyptus } \\
\text { chips }\end{array}$ & Autohydrolysis treatment & Cellulose & Bioethanol & [11] \\
\hline $\begin{array}{l}\text { Paper } \\
\text { sludge }\end{array}$ & Enzymatic saccharification & Cellulose & Lactic acid & [17] \\
\hline $\begin{array}{l}\text { Paper } \\
\quad \text { sludge }\end{array}$ & $\begin{array}{l}\text { Enzymatic hydrolysis, } \\
\text { fermentation }\end{array}$ & Cellulose & Ethanol & [19] \\
\hline $\begin{array}{l}\text { Pine } \\
\text { sawdust }\end{array}$ & $\begin{array}{l}\mathrm{NaOH} \text { delignification } \\
\text { pretreatment, pulp } \\
\text { treatment, TEMPO- } \\
\text { mediated oxidation, } \\
\text { mechanical treatment }\end{array}$ & Cellulose & Nanocellulose & [25] \\
\hline $\begin{array}{l}\text { Paper } \\
\quad \text { sludge }\end{array}$ & $\begin{array}{l}\text { Fermentation for biogas } \\
\text { production }\end{array}$ & $\begin{array}{l}\text { Organic } \\
\text { matter }\end{array}$ & $\begin{array}{l}\text { Volatile fatty } \\
\text { acids }\end{array}$ & {$[26]$} \\
\hline $\begin{array}{l}\text { Waste fiber } \\
\text { sludge }\end{array}$ & $\begin{array}{l}\text { Enzymatic hydrolysis and } \\
\text { fermentation }\end{array}$ & $\begin{array}{l}\text { Glucose from } \\
\text { cellulose } \\
\text { hydrolysis }\end{array}$ & $\begin{array}{l}\text { Bacterial } \\
\quad \text { cellulose }\end{array}$ & {$[27]$} \\
\hline $\begin{array}{l}\text { Eucalyptus } \\
\text { chips }\end{array}$ & $\begin{array}{l}\text { Autohydrolysis treatment, } \\
\text { acid hydrolysis, } \\
\text { fermentation }\end{array}$ & Hemicellulose & Bioethanol & {$[28]$} \\
\hline $\begin{array}{l}\text { Eucalyptus } \\
\text { chips }\end{array}$ & $\begin{array}{l}\text { Autohydrolysis treatment, } \\
\text { fermentation }\end{array}$ & Hemicellulose & Oligosaccharides & {$[29]$} \\
\hline $\begin{array}{l}\text { Pine } \\
\quad \text { residues }\end{array}$ & $\begin{array}{l}\text { Compressed } \mathrm{CO}_{2} \\
\text { extraction }\end{array}$ & Lignin & $\begin{array}{l}\text { Phenolic and } \\
\text { lipophilic } \\
\text { compounds }\end{array}$ & {$[30]$} \\
\hline $\begin{array}{l}\text { Eucalyptus } \\
\text { bark }\end{array}$ & $\begin{array}{l}\text { Supercritical } \mathrm{CO}_{2} \text { fluid } \\
\text { extraction }\end{array}$ & Extractives & Triterpenic acid & {$[31]$} \\
\hline
\end{tabular}

production of the product of interest. These pretreatments enable to access the desired fraction for the production of value-added products such as biofuels (ethanol), acid lactic (a building block for the production of polylactic acid, PLA), oligosaccharides derived from hemicellulosic fraction (used as prebiotic), or phenolic compounds with antioxidant activity (produced by depolymerization of lignin).

\subsection{Wastes From Wine-Making}

Grape crop production is more than 60 million tons every year and almost 23 million tons corresponding to European contributors. Grape production includes fresh consumption as table fruit, juice, and raisins, but the major use of grape is in the wine production by the vinification process [32]. The wine-making sector is considered one of the most 
important beverage industries. Worldwide wine production is about 280 million hectoliters $[4,33]$. The European Union is the greater wine producer in the world, responsible for the commercialization of 60\% of world's wine [34]. A 48\% (3.6 million ha) of global total area harvest of the vineyard is placed in Europe. The largest producer countries are in Southwestern Europe (Italy, France, Greece, Portugal, and Spain). These countries are responsible for $48 \%$ of global wine production [32].

The harvest of the vine and the process of wine elaboration (also known as vinification) involve seasonal stages that generate a lot of residues (including product enriched with bioactive compounds as phenolic compounds) [3]. These residues represent up to $30 \%$ of the material used for the wine elaboration [32]. Among these wastes, it is important to highlight (i) biomass derived from pruning of vine, (ii) grape stalk from the destemming stage, and (iii) grape marc or grape pomace obtained from pressing stage. In this regard, 14.5 million tons of grape by-products is produced in Europe, annually [35].

Briefly, the main steps of the wine processing are summarized below (Fig. 16.3). The bunch of grapes are harvested mechanically or by hand. The stems are separated from grapes and are crushed before the fermentation process. Fermentation is carried out by yeast already present on the grapes. Days after maceration (fermentation), grape

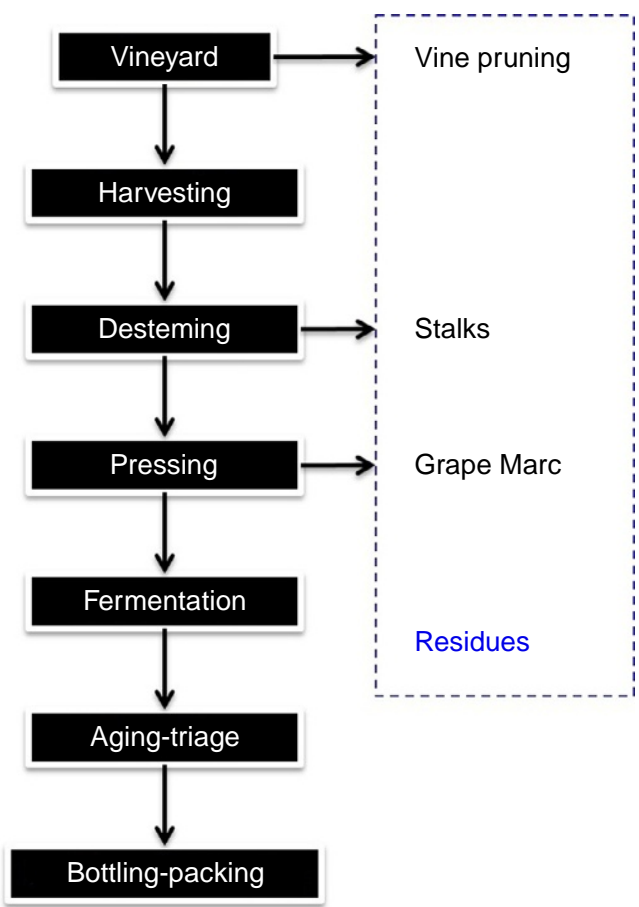

Fig. 16.3 Main stages of vinification and residues generated. 
pomace (also known as grape marc) is pressed by a pneumatic press for the separation of wine. Subsequently, the malolactic fermentation is induced by inoculation with lactic acid bacteria strain [36].

Residue chemical composition determines further valorization, therefore considering the following:

- Vine pruning residue: the pruning is the result of the annual vine pruning representing about $5 \%$ of the wine residue. This lignocellulosic residue is composed of a significant percentage of cellulose $(32.0 \%-49.0 \%)$ followed by lignin $(21.0 \%-26.4 \%)$ and hemicelluloses $(11.2 \%-13.6 \%)$ [37].

- Grape stalk: due to the high content of lignin, it is an important waste produced during wine making. The stalks are composed of cellulose $(20.1 \%-37.0 \%)$, hemicellulose $(4.8 \%-35.3 \%)$, and lignin $(2.0 \%-56.1 \%)$ [38].

- Grape pomace: it is composed of cellulose $(20.8 \%-48.2 \%)$, hemicellulose $(4.8 \%-35.3 \%)$, and lignin $(16.8 \%-24.2 \%)$ [32]. Grape pomace is a rich source of phenolic acids, colored anthocyanins, flavonoids, and tannins. Its composition is related to the grape variety, the processing method, the environmental conditions, and the proportion of the skin, seeds, and cuttings [39]. These compounds are extracted from waste sources and used in food, cosmetic, and pharmaceutical industries.

Recent works in the literature have reported alternative processes for valorization of these residues. Table 16.2 shows pretreatments employed for the residue processing and the final product. A suitable pretreatment technology allows the extraction of a more accessible fraction to obtain value-added products such as phenolic compounds, lactic acid, xylitol, bioadsorbents, and oligosaccharides (Table 16.2). The extraction of phenolic compounds is the main issue of most addressed of the works in literature with this kind of residues due to their interesting biological activities as an antioxidant compound [40].

\subsection{Brewery Wastes}

The European Union is the second-largest beer producer in the world with a production of 383 million hectoliters per year in 2014 [47]. Brewing industry presents singular features in each state member with about 6,500 breweries placed in the United Kingdom, Germany, and France. Fig. 16.4 shows the beer production process and the generation of residues. Beer production process differs from brewery to brewery and according to beer types, brewery equipment, and national legislation. Nevertheless, the process involves the following main stages: malting, mashing, lautering, boiling, fermenting, conditioning, filtering, and bottling (Fig. 16.4).

Several raw materials are necessary in the production process of beer, including barley malt, adjuncts, hops, water, and yeast. In the brewing industry, a lot of organic waste materials are generated such as spent grain, spent hops, and residual yeast (surplus yeast) [48]. Moreover, wastewater can be considered a residue from brewing industry with potential for bioenergy production as biodiesel and microbial fuel cells [49,50]. 
Table 16.2 Valorization of residues from wine-making industry: pretreatment used and main product obtained

\begin{tabular}{|c|c|c|c|c|}
\hline Raw material & Pretreatment & Fraction & Value-added product & Reference \\
\hline Vine pruning & Autohydrolysis treatment & Hemicellulose & Oligosaccharides & {$[37]$} \\
\hline $\begin{array}{l}\text { Grape stalk and } \\
\text { grape pomace }\end{array}$ & Extraction with ethanol & $\begin{array}{l}\text { Cellulose and } \\
\text { hemicellulose }\end{array}$ & Dietary fiber & [39] \\
\hline Vine pruning & Acid hydrolysis, alkali extraction & Lignin & Phenolic acids & [40] \\
\hline Vine pruning & $\begin{array}{l}\text { Alkaline pretreatment, enzymatic } \\
\text { hydrolysis }\end{array}$ & Cellulose & Glucose & [41] \\
\hline Grape pomace & Extraction with methanol & Extractives & Phenolic-rich extract & {$[42]$} \\
\hline Vine pruning & Acid hydrolysis & Cellulose and lignin & Bioadsorbent & [43] \\
\hline Vine pruning & Acid hydrolysis, fermentation & Hemicellulose & Xylitol and lactic acid & {$[44]$} \\
\hline $\begin{array}{l}\text { Grape skin from } \\
\text { grape pomace }\end{array}$ & $\begin{array}{l}\text { Extraction with hexane and water, acid } \\
\text { hydrolysis, and fermentation }\end{array}$ & $\begin{array}{l}\text { Cellulose } \\
\text { Extractives } \\
\text { containing soluble } \\
\text { sugars }\end{array}$ & $\begin{array}{l}\text { Biocomposites } \\
\text { Ethanol }\end{array}$ & [45] \\
\hline Grape pomace & Acid hydrolysis, fermentation & Hemicellulose & $\begin{array}{l}\text { Lactic acid and } \\
\text { intracellular } \\
\text { biosurfactants }\end{array}$ & [46] \\
\hline
\end{tabular}




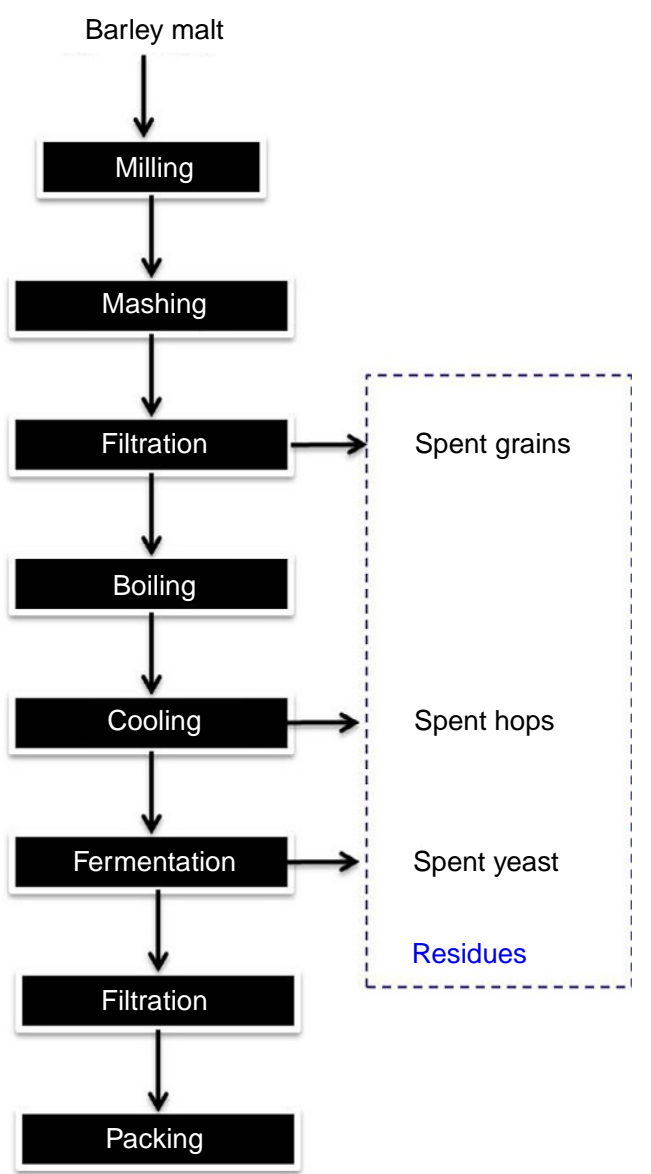

Fig. 16.4 Main stages of beer making and residues generated.

Brewer's spent grain (solid fraction of barley malt) is the most studied and revalorized residue from beer processing due to its high carbohydrate content (up to 50\%) and protein (up to 30\%) [51]. This residue is usually used for animal feed. Table 16.3 presents research works of spent grain valorization through pretreatment fractionation and conversion to a desirable product.

Another interesting residue generated in beer processing is the spent hops. Its composition includes fibers (composed by chains of rhamnose, arabinose, mannose, galactose, xylose, and glucose), nitrogen-free extract, and proteins [48]. Usually, spent hops are used as soil fertilizer due to high nitrogen content. Other high-value-added compounds can be potentially obtained from spent hops (such as flavors, saccharides, and organic acids by oxidation or hydrolysis) [48]. Moreover, spent brewer's yeast is obtained in the end of the fermentation process. Yeast waste is mainly used as protein source in animal feed. 
Table 16.3 Valorization of brewery wastes: pretreatment used and main product obtained

\begin{tabular}{|c|c|c|c|c|}
\hline Raw material & Pretreatment & Fraction & $\begin{array}{l}\text { Value-added } \\
\text { product }\end{array}$ & Reference \\
\hline Brewer's spent grain & $\begin{array}{l}\text { Sequential water } \\
\text { and alkali } \\
\text { extractions }\end{array}$ & Hemicellulose & Arabinoxylan & {$[51]$} \\
\hline Spent brewer's yeast & Alkaline treatment & Yeast cell walls & $\beta$-glucan & {$[52]$} \\
\hline Brewer's spent grain & $\begin{array}{l}\text { Steam explosion, } \\
\text { enzymatic } \\
\text { saccharification }\end{array}$ & Cellulose & Glucose & {$[53]$} \\
\hline Brewer's spent grain & $\begin{array}{l}\mathrm{CO}_{2} \text { supercritical } \\
\text { extraction }\end{array}$ & & $\begin{array}{l}\text { Phenolic } \\
\text { compound } \\
\text { and flavonoids }\end{array}$ & {$[54]$} \\
\hline $\begin{array}{l}\text { Spent yeast } \\
\text { Brewer's spent grain }\end{array}$ & $\begin{array}{l}\text { Enzymatic } \\
\text { hydrolysis }\end{array}$ & & $\begin{array}{l}\text { Phenolic } \\
\text { compounds }\end{array}$ & {$[55]$} \\
\hline Brewer's spent grain & $\begin{array}{l}\text { Autohydrolysis } \\
\text { treatment }\end{array}$ & Cellulose & Lactic acid & {$[56]$} \\
\hline Brewery yeast waste & $\begin{array}{l}\text { Aqueous two- } \\
\text { phase system }\end{array}$ & Intracellular & $\begin{array}{l}\text { Invertase } \\
\text { recovery }\end{array}$ & {$[57]$} \\
\hline Brewer's spent grains & $\begin{array}{l}\text { Fungal } \\
\text { consolidated } \\
\text { bioprocessing }\end{array}$ & Cellulose & Bioethanol & {$[58]$} \\
\hline Brewer's spent grain & $\begin{array}{l}\text { Autohydrolysis, } \\
\text { enzymatic } \\
\text { saccharification }\end{array}$ & Cellulose & Glucose & {$[59]$} \\
\hline
\end{tabular}

Nevertheless, some works reported the potential of yeast residue as bioadsorbent for the metal adsorption in wastewater [60]. Table 16.3 also shows some works in which yeast cells are disrupted by mechanical or chemical pretreatment to break down its cellular structure to recover value-added products such as $\beta$-glucan used to improve health and immune systems of humans and animals [52].

\subsection{Residues From the Dairy Industry}

The dairy industry represents one of the main economic sectors in Europe. The European dairy industry contributes $14 \%$ to the overall EU agricultural income. A large number of companies (more than $80 \%$ industries of the dairy sector) are small and mid-size companies. [61]. During the processing of milk for the elaboration of dairy products (such as yogurt, cheese, buttermilk, butter, milk, and creams), several by-products are generated. Whey is one of these by-products, obtained after cheese production or in the elimination of fat and casein from milk. Cheese whey retains most of the milk lactose. Apart from lactose $\left(39-60 \mathrm{~kg} / \mathrm{m}^{3}\right)$, cheese effluents also contain proteins $\left(1.4-33.5 \mathrm{~kg} / \mathrm{m}^{3}\right)$ and fats 
$\left(0.99-10.58 \mathrm{~kg} / \mathrm{m}^{3}\right)$, mineral salts $(0.46 \%-10 \%)$, calcium salts, lactic acid, citric acid, urea, and others [62]. Last 50 years, cheese whey has been wasted in the soil, which causes environmental damages due to high protein content.

Cheese whey wastewater is also produced in large quantities. In fact, $9 \mathrm{~kg}$ of cheese whey and $2.3 \mathrm{~L}$ of cheese whey wastewater per $\mathrm{kg}$ of cheese are generated [63,64]. Currently, technology has advanced to use cheese whey in the market as a functional ingredient in foods and as a nutrient in dietetic foods. Cheese whey is composed of value-added components such as protein, minerals, and sugars (mainly lactose).

The separation methods used to recover and separate these value-added compounds are membrane technology, crystallization, and chromatographic process. [65]. The protein-rich fraction is usually isolated, denominated commonly by whey protein concentrate (WPC), since it has several applications in the food industry. The WPC can be fractionated for the isolation of specific peptides or used directly as a whole [66]. The proteins from milk have been used in the production of functional foods or pharmaceutical formulations [4]. A high-volume and high-pollutant stream mainly composed by lactose remains after protein removal. This lactose stream may be used to produce bioethanol [67] and to produce simultaneously $\beta$-galactosidase and bioethanol by engineered yeast strains [68] or lactose-derived nutraceuticals (such as lactulose, lactosucrose, lactitol, lactobionic acid, gluconic acid, lactone, and tagatose) $[69,70]$. Also, lactose and its derivatives are used in the food and confectionery industry as an additive that prolongs storage life, increasing the weight of products (filler) without altering the flavor, etc., and in the pharmaceutical industry as an excipient. Cheese whey is also used in nonfood applications such as protein-based films and biomaterials [4]. Table 16.4 includes some of the most recent studies of dairy residue valorization.

Table 16.4 Valorization of cheese whey: pretreatment used and main product obtained

\begin{tabular}{|c|c|c|c|c|}
\hline Raw material & Pretreatment & Fraction & $\begin{array}{l}\text { Value-added } \\
\text { product }\end{array}$ & Reference \\
\hline Cheese whey & $\begin{array}{r}\text { Ultrafiltration } \\
\text { technology }\end{array}$ & Whey & Protein and sugars & {$[65]$} \\
\hline Cheese whey & $\begin{array}{l}\text { Enzymatic process } \\
\text { Chemical process }\end{array}$ & Lactose & Lactulose & [70] \\
\hline Cheese whey & Fermentation & Lactose & Ethanol & [71] \\
\hline Cheese whey & Fermentation & Lactose & $\beta$-galactosidase & {$[72]$} \\
\hline Cheese whey & $\begin{array}{l}\text { Alcalase hydrolysis, } \\
\text { fermentation }\end{array}$ & Lactose, protein & Hyaluronic acid & [73] \\
\hline Cheese whey & $\begin{array}{l}\text { Membrane filtration } \\
\text { technology }\end{array}$ & Whey & Whey proteins & [74] \\
\hline
\end{tabular}




\section{CONCLUSIONS AND PERSPECTIVES}

This chapter describes some of the main industrial processes in Southwestern Europe, identifying the residues generated (viz., pulp and paper residues, brewer's residues, dairy residues, and wine-making wastes). As the general trend, these residues are used as a whole for biofuel production (such as biogas), as a lower investment is required in this process when compared with the fractionated use. Nevertheless, the valorization of fractions that resulted from biomass processing allows the production of several products, in an analogy to the petroleum refinery, which contributes to sustainable growth based on renewable energy sources. On the other hand, structure and chemical composition of these residues determine the selection of the fractionation process to be used and are the main keys to an efficient fractionation process and thus should be carefully considered.

A large number of works in the literature show the possibility to obtain several products of industrial interest (as biofuels, biomaterials, and bioactive compounds) using environmentally friendly technologies. Most of these pretreatments allow the attainment of high yields of the final product. Nevertheless, most of these works describe the valorization of only one fraction (such as cellulose to obtain glucose). Nowadays, an integral valorization of all streams generated in the processes should be taken into account to attain a feasible and sustainable process. This goal would be achieved by the combination of several pretreatments obtaining a biorefinery based on a multistep processing. The most promising combined pretreatment is the hydrothermal treatment followed by an enzymatic hydrolysis of the solid fraction that allows the hemicellulose solubilization (as oligosaccharides), the saccharification of cellulose into glucose, and the lignin recovery at the end of the enzymatic hydrolysis. Alternatively, hydrothermal treatment followed by a delignification treatment (such as organosol) shows interesting results on enzymatic saccharification improvement of cellulose, oligosaccharide production in a separated stream, and sulfur-free lignin recovery with interesting features. This chapter shows the potential use of residue fractions for value-added compound production and the required treatment. Nevertheless, most of these processes are not large-scale developed being a necessary high-initial investment.

Industries have the resources for the waste transformation and the know-how, being possible to adapt their installations for the integral valorization of residue biomass. Still, the seasonality of production and the heterogeneous composition of the residues are the main obstacles implementing this approach. These challenges would be addressed from an integrated perspective, taking into account the residue producers, the fractionated process to produce more than one value-added product, the cost of processing, and the product market. All together could contribute to attaining a sustainable economic growth in regions of Southern Europe. 


\section{ACKNOWLEDGMENTS}

This study was supported by the Portuguese Foundation for Science and Technology (FCT) under the scope of the strategic funding of UID/BIO/04469/2013 unit and COMPETE 2020 (POCI-01-0145FEDER-006684) and BioTecNorte operation (NORTE-01-0145-FEDER-000004) funded by European Regional Development Fund under the scope of Norte2020-Programa Operacional Regional do Norte. Michele Michelin is recipient of FCT fellowships (SFRH/BPD/100786/2014).

\section{REFERENCES}

[1] P. Gullón, A. Romaní, C. Vila, G. Garrote, J.C. Parajó, Potential of hydrothermal treatments in lignocellulose biorefineries, Biofuels Bioprod. Biorefin. 6 (2) (2012) 219-232.

[2] B. Elbersen, I. Startisky, G. Hengeveld, M.-J. Schelhaas, H. Naeff, Atlas of EU biomass potentialsdeliverable 3.3: spatially detailed and quantified overview of EU biomass potential taking into account the main criteria determining biomass availability from different sources, IEE 08653 SI2. 529241 (2012).

[3] R. Devesa-Rey, X. Vecino, J.L. Varela-Alende, M.T. Barral, J.M. Cruz, A.B. Moldes, Valorization of winery wastes vs. the costs of not recycling, Waste Manag. 31 (11) (2011) 2327-2335.

[4] C.S.K. Lin, A.A. Koutinas, K. Stamatelatou, E.B. Mubofu, A.S. Matharu, N. Kopsahelis, L.A. Pfaltzgraff, J.H. Clark, S. Papanikolaou, T.H. Kwan, R. Luque, Current and future trends in food waste valorization for the production of chemicals, materials and fuels: a global perspective, Biofuels Bioprod. Biorefin. 8 (5) (2014) 686-715.

[5] Z. Wysokińska, The "New" environmental policy of the European Union: a path to development of a circular economy and mitigation of the negative effects of climate change, Comp. Econ. Res. 19 (2016) $57-73$.

[6] S. Searle, C. Malins, Availability of Cellulosic Residues and Wastes in the EU, International Council on Clean Transportation, Washington, DC, 2013.

[7] A. Scoma, S. Rebecchi, L. Bertin, F. Fava, High impact biowastes from South European agroindustries as feedstock for second-generation biorefineries, Crit. Rev. Biotechnol. 36 (2016) 175-189.

[8] N. Scarlat, M. Martinov, J.-F. Dallemand, Assessment of the availability of agricultural crop residues in the European Union: potential and limitations for bioenergy use, Waste Manag. 30 (2010) 1889-1897.

[9] M. De Wit, A. Faaij, European biomass resource potential and costs, Biomass Bioenergy 34 (2) (2010) 188-202.

[10] P. Alvira, E. Tomás-Pejó, M. Ballesteros, M.J. Negro, Pretreatment technologies for an efficient bioethanol production process based on enzymatic hydrolysis: a review, Bioresour. Technol. 101 (2010) 4851-4861.

[11] A. Romaní, G. Garrote, J.L. Alonso, J.C. Parajó, Experimental assessment on the enzymatic hydrolysis of hydrothermally pretreated Eucalyptus globulus wood, Ind. Eng. Chem. Res. 49 (10) (2010) 4653-4663.

[12] A. Romaní, G. Garrote, F. López, J.C. Parajó, Eucalyptus globulus wood fractionation by autohydrolysis and organosolv delignification, Bioresour. Technol. 102 (10) (2011) 5896-5904.

[13] R. Luque, J. Clark, Valorisation of food residues: waste to wealth using Green chemical technologies, Sustain. Chem. Process. 1 (2013) 10.

[14] L. Hetemaki, Future of the European Forest-Based Sector: Structural Changes Towards Bioeconomy, European Forest Institute, 2014.

[15] M.C. Monte, E. Fuente, A. Blanco, C. Negro, Waste management from pulp and paper production in the European Union, Waste Manag. 29 (2009) 293-308.

[16] D. Gavrilescu. Energy from biomass in pulp and paper mills, Environ. Eng. Manag. J. 7(5), (2008) 537-546. 
[17] A. Romaní, R. Yáñez, G. Garrote, J.L. Alonso, SSF production of lactic acid from cellulosic biosludges, Bioresour. Technol. 99 (10) (2008) 4247-4254.

[18] P. Bajpai, Generation of waste in pulp and paper mills, in: Management of pulp and paper mill waste, Springer, Switzerland, 2015. Chapter 2.

[19] D. Gomes, L. Domingues, M. Gama, Valorizing recycled paper sludge by a bioethanol production process with cellulase recycling, Bioresour. Technol. 216 (2016) 637-644.

[20] F.J. Aukour, Feasibility study of manufacturing concrete eco-blocks using marble sludge powder as raw materials, WIT Trans. Ecol. Environ. 120 (2009) 845-852.

[21] Y. Tong, B.K. Mayer, P.J. McNamara, Triclosan adsorption using wastewater biosolids-derived biochar, Environm. Sci. Water Res. Technol. 2 (4) (2016) 761-768.

[22] C. Priadi, D. Wulandari, I. Rahmatika, S.S. Moersidik, Biogas production in the anaerobic digestion of paper sludge, APCBEE Procedia 9 (2014) 65-69.

[23] E.M. Nkhalambayausi-Chirwa, M.T. Lebitso, Assessment of nutritional value of single-cell protein from waste-activated sludge as a protein supplement in poultry feed, Water Environ. Res. 84 (12) (2012) 2106-2114.

[24] L. Wang, J.G. Wang, J. Littlewood, H.B. Cheng, Co-production of biorefinery products from kraft paper sludge and agricultural residues: opportunities and challenges, Green Chem. 16, (2014) 1527-1533.

[25] N.V. Ehman, Q. Tarrés, M. Delgado-Aguilar, M.E. Vallejos, F. Felissia, M.C. Area, P. Mutjé, From Pine sawdust to cellulose nanofibers. Cellul. Chem. Technol. 50, (2016) 361-367.

[26] S. Bayr, J. Rintala, Thermophilic anaerobic digestion of pulp and paper mill primary sludge and co-digestion of primary and secondary sludge, Water Res. 46 (15) (2012) 4713-4720.

[27] A. Cavka, X. Guo, S.J. Tang, S. Winestrand, L.J. Jönsson, F. Hong, Production of bacterial cellulose and enzyme from waste fiber sludge, Biotechnol. Biofuels 6 (1) (2013) 25.

[28] J. Rodríguez-López, A.J. Sánchez, D.M. Gómez, A. Romaní, J.C. Parajó, Fermentative production of fumaric acid from Eucalyptus globulus wood hydrolysates, J. Chem. Technol. Biotechnol. 87 (7) (2012) 1036-1040.

[29] P. Gullón, M.J. González-Muñoz, H. Domínguez, J.C. Parajó, Membrane processing of liquors from Eucalyptus globulus autohydrolysis, J. Food Eng. 87 (2) (2008) 257-265.

[30] E. Conde, J. Hemming, A. Smeds, B.D. Reinoso, A. Moure, S. Willför, H. Domínguez, J.C. Parajó, Extraction of low-molar mass phenolics and lipophilic compounds from Pinus pinaster wood with compressed $\mathrm{CO}_{2}$, J. Supercrit. Fluids 81 (2013) 193-199.

[31] M.M.R. De Melo, R.M.A. Domingues, M. Sova, E. Lack, H. Seidlitz, F.J. Lang, A.J.D. Silvestre, C.M. Silva, Scale-up studies of the supercritical fluid extraction of triterpenic acids from Eucalyptus globulus bark, J. Supercrit. Fluids 95 (2014) 44-50.

[32] A. Teixeira, N. Baenas, R. Dominguez-Perles, A. Barros, E. Rosa, D.A. Moreno, C. GarciaViguera, Natural bioactive compounds from winery by-products as health promoters: a review, Int. J. Mol. Sci. 15 (9) (2014) 15638-15678.

[33] OIV-Organisation Internationale de la Vigne et du Vin, Global economic vitiviniculture data, 2013. Available at http://www.oiv.int/oiv/info/enpoint2013.

[34] K. Deconinck, J. Swinnen, The economics of planting rights in wine production, Eur. Rev. Agric. Econ. 42 (3) (2015) 419-440.

[35] V. Chouchouli, N. Kalogeropoulos, S.J. Konteles, E. Karvela, D.P. Makris, V.T. Karathanos, Fortification of yoghurts with grape (Vitis vinifera) seed extracts, Food Sci. Technol. 53 (2013) 522-529.

[36] F. Torchio, D.E. Urcan, L. Lin, V. Gerbi, S. Giacosa, S. Río Segade, N. Pop, M. Lambri, L. Rolle, Influence of different withering conditions on phenolic composition of Avanà, Chatus and Nebbiolo grapes for the production of 'Reinforced' wines, Food Chem. 194 (2016) 247-256.

[37] I. Dávila, O. Gordobil, J. Labidi, P. Gullón, Assessment of suitability of vine shoots for hemicellulosic oligosaccharides production through aqueous processing, Bioresour. Technol. 211 (2016) 636-644. 
[38] D. Amendola, D.M. De Faveri, I. Egües, L. Serrano, J. Labidi, G. Spigno, Autohydrolysis and organosolv process for recovery of hemicelluloses, phenolic compounds and lignin from grape stalks, Bioresour. Technol. 107 (2012) 267-274.

[39] M.R. González-Centeno, C. Rosselló, S. Simal, M.C. Garau, F. López, A. Femenia, Physico-chemical properties of cell wall materials obtained from ten grape varieties and their byproducts: grape pomaces and stems, LWT-Food Sci. Technol. 43 (10) (2010) 1580-1586.

[40] B. Max, A.M. Torrado, A.B. Moldes, A. Converti, J.M. Domínguez, Ferulic acid and p-coumaric acid solubilization by alkaline hydrolysis of the solid residue obtained after acid prehydrolysis of vine shoot prunings: effect of the hydroxide and pH, Biochem. Eng. J. 43 (2) (2009) 129-134.

[41] F. Cotana, M. Barbanera, D. Foschini, E. Lascaro, C. Buratti, Preliminary optimization of alkaline pretreatment for ethanol production from vineyard pruning, Energy Procedia 82 (2015) 389-394.

[42] L. García-Becerra, M. Mitjans, C. Rivas-Morales, J. Verde-Star, A. Oranday-Cárdenas, P.M. Vinardell, Antioxidant comparative effects of two grape pomace Mexican extracts from vineyards on erythrocytes, Food Chem. 194 (2016) 1081-1088.

[43] X. Vecino, R. Devesa-Rey, A.B. Moldes, J.M. Cruz, Formulation of an alginate-vineyard pruning waste composite as a new eco-friendly adsorbent to remove micronutrients from agroindustrial effluents, Chemosphere 111 (2014) 24-31.

[44] O. Portilla-Rivera, A. Torrado, J.M. Domínguez, A.B. Moldes, Stability and emulsifying capacity of biosurfactants obtained from lignocellulosic sources using Lactobacillus pentosus, J. Agric. Food Chem. 56 (17) (2008) 8074-8080.

[45] J.A.S. Mendes, S.O. Prozil, D.V. Evtuguin, L.P.C. Lopes, Towards comprehensive utilization of winemaking residues: characterization of grape skins from red grape pomaces of variety Touriga Nacional, Ind. Crop. Prod. 43 (1) (2013) 25-32.

[46] O.M.P. Rivera, A.B. Moldes, A.M. Torrado, J.M. Domínguez, Lactic acid and biosurfactants production from hydrolyzed distilled grape marc, Process Biochem. 42 (6) (2007) 1010-1020.

[47] EU Report (2016). The Contribution made by Beer to the European Economy. In: "The Brewers of Europe”. ISBN 978-2-9601382-6-9.

[48] S.I. Mussatto, Brewer's spent grain: a valuable feedstock for industrial applications, J. Sci. Food Agric. 94 (7) (2014) 1264-1275.

[49] G.A. Lutzu, W. Zhang, T. Liu, Feasibility of using brewery wastewater for biodiesel production and nutrient removal by Scenedesmus dimorphus, Environ. Technol. (UK) 37 (12) (2016) 1568-1581.

[50] J.M. Angosto, J.A. Fernández-López, C. Godínez, Brewery and liquid manure wastewaters as potential feedstocks for microbial fuel cells: a performance study, Environ. Technol. 36 (1-4) (2016) 68-78.

[51] E. Coelho, M.A. Rocha, A.S.P. Moreira, M.R.M. Domingues, M.A. Coimbra, Revisiting the structural features of arabinoxylans from brewer's spent grain, Carbohydr. Polym. 139 (2016) 167-176.

[52] V. Zechner-krpan, V. Petravic-Tominac, P. Galovic, V. Galovic, J. Filipovic-Grcic, S. Srecec, Application of different drying methods on $\beta$-glucan isolated from spent brewer's yeast using alkaline procedure, Agric. Conspec. Sci. 75, (2010) 45-50.

[53] K. Kemppainen, K. Rommi, U. Holopainen, K. Kruus, Steam explosion of Brewer's spent grain improves enzymatic digestibility of carbohydrates and affects solubility and stability of proteins, Appl. Biochem. Biotechnol. 180 (1) (2016) 94-108.

[54] S. Spinelli, A. Conte, L. Lecce, L. Padalino, M.A. Del Nobile, Supercritical carbon dioxide extraction of brewer's spent grain, J. Supercrit. Fluids 107 (2016) 69-74.

[55] E.F. Vieira, J. Carvalho, E. Pinto, S. Cunha, A.A. Almeida, I.M.P.L.V.O. Ferreira, Nutritive value, antioxidant activity and phenolic compounds profile of brewer's spent yeast extract, J. Food Compos. Anal. 52 (2016) 44-51.

[56] A. Djukić-Vuković, D. Mladenović, M. Radosavljević, S. Kocić-Tanackov, J. Pejin, L. Mojović, Wastes from bioethanol and beer productions as substrates for $1(+)$ lactic acid production-a comparative study, Waste Manag. 48 (2016) 478-482.

[57] G. León-González, J. González-Valdez, K. Mayolo-Deloisa, M. Rito-Palomares, Intensified fractionation of brewery yeast waste for the recovery of invertase using aqueous two-phase systems, Biotechnol. Appl. Biochem. 63 (6) (2016) 886-894. 
[58] S. Wilkinson, K.A. Smart, S. James, D.J. Cook, Bioethanol production from brewers spent grains using a fungal consolidated bioprocessing (CBP) approach, Bioenergy Res. 10(1) (2016) 146-157.

[59] M. Michelin, J.A. Teixeira, Liquid hot water pretreatment of multi feedstocks and enzymatic hydrolysis of solids obtained thereof, Bioresour. Technol. 216 (2016) 862-869.

[60] K. Parvathi, R. Nagendran, R. Nareshkumar, Lead biosorption onto waste beer yeast by-product, a means to decontaminate effluent generated from battery manufacturing industry, Electron. J. Biotechnol. 10 (1) (2007).

[61] EDA-European Dairy Association (2016). Economic Report 2016/17. Available at: http://www. euromilk.org.

[62] A.R. Prazeres, F. Carvalho, J. Rivas, Cheese whey management: a review, J. Environ. Manag. 110 (2012) 48-68.

[63] M.I.G. Siso, The biotechnological utilization of cheese whey: a review, Bioresour. Technol. 57 (1) (1996) 1-11.

[64] A.P. Economopoulos, Assessment of Sources of Air, Water and Soil Pollution: A Guide to Rapid Source Inventory Techniques and Their Use in Formulating Environmental Control Strategies, World Health Organization, 1993.

[65] C.M. Galanakis, S. Chasiotis, G. Botsaris, V. Gekas, Separation and recovery of proteins and sugars from Halloumi cheese whey, Food Res. Int. 65 (2014) 477-483.

[66] N. Estévez, P. Fuciños, A.C. Sobrosa, L. Pastrana, N. Pérez, M.L. Rúa, Modeling the angiotensinconverting enzyme inhibitory activity of peptide mixtures obtained from cheese whey hydrolysates using concentration-response curves, Biotechnol. Prog. 28 (5) (2012) 1197-1206.

[67] P.M.R. Guimarães, J.A. Teixeira, L. Domingues, Fermentation of lactose to bio-ethanol by yeasts as part of integrated solutions for the valorisation of cheese whey, Biotechnol. Adv. 28 (3) (2010) $375-384$.

[68] L. Domingues, J. Teixeira, M. Penttilä, N. Lima, Construction of a flocculent Saccharomyces cerevisiae strain secreting high levels of Aspergillus niger $\beta$-galactosidase, Appl. Microbiol. Biotechnol. 58 (5) (2002) 645-650.

[69] A. Nath, B. Verasztó, S. Basak, A. Koris, Z. Kovács, G. Vatai, Synthesis of lactose-derived nutraceuticals from dairy waste whey—a review, Food Bioprocess Technol. 9 (1) (2016) 16-48.

[70] S.C. Silvério, E.A. Macedo, J.A. Teixeira, L.R. Rodrigues, Biocatalytic approaches using lactulose: endo product compared with substrate, Compr. Rev. Food Sci. Food Saf. 15 (5) (2016) 878-896.

[71] L. Domingues, P.M.R. Guimarães, C. Oliveira, Metabolic engineering of Saccharomyces cerevisiae for lactose/whey fermentation, Bioeng. Bugs 1 (3) (2010) 164-171.

[72] I. Castro, C. Oliveira, L. Domingues, J.A. Teixeira, A.A. Vicente, The effect of the electric field on lag phase, $\beta$-galactosidase production and plasmid stability of a recombinant Saccharomyces cerevisiae strain growing on lactose, Food Bioprocess Technol. 5 (8) (2012) 3014-3020.

[73] I.R. Amado, J.A. Vázquez, L. Pastrana, J.A. Teixeira, Cheese whey: a cost-effective alternative for hyaluronic acid production by Streptococcus zooepidemicus, Food Chem. 198 (2016) 54-61.

[74] A. Akpinar-Bayizit, T. Ozcan, L. Yilmaz-Ersan, Membrane processes in production of functional whey components, Mljekarstvo, 59, (2009) 282-288. 